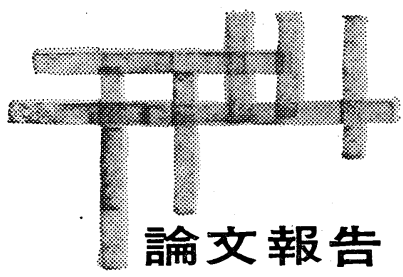

\section{別子鉱山における通気改善および}

\section{坑内冷却についで}

\author{
（昭和36年度 渡辺賞牌受賞）
}

正会員天野 熏 三**

\title{
Underground Air Coditioning at Bessi Mine
}

\section{Kunzo AMANO}

As for the plan of improving the meteorological condition in the hot underground, two methods are usually adopted; one is by means of increasing ventilation volume, and another is by cooling air artificially with the refrigerator. In the adoption of the former method, the relation between ventilation volume and the temperature of air current, the effect of wetness of rock surface, thermal conductivity of rocks, and radius of mine gallery on the temperature of air current come into question. And regarding the latter method, the setting place of the refrigerator or the cooler comes into question.

In this paper we discussed these problems citing some examples, and further set forth the cooling. method using cool water. We noted down here that since these devices were brought in operation, the meteorological condition in Bessi Mine has been improved and prospects of success in the deep mining was realized.

\section{1. 緒}

言

別子鉱山は採鉣開始以来 270 年の歴史を持ち，現在ま でに粗鉣量 2,300 万 $\mathrm{t}$, 銅量 64 万 $\mathrm{t}$ を座出したわが国最 大の銅山であるが，稼行年数の増加とともに採鉱切羽が 深部に移行し, 坑内気温が上昇したため, 坑内冷却の問 題が重要な研究課題となつた。

暑い坑内の気象条件を改善する方法としては, 通気量 を堌加する方法と, 冷凍機などを使用して坑内を人工的 な手段によつて冷却する方法とが採用されている。これ らの方法のうち前者では, 通気量と気流温度との関係お よび岩盤壁面の濡れの状態, 岩盤の熱伝導度, 坑道半径 などが気流温度にどのような影響をおよぼすかが問題と なり, また後者では, 泠凍機または空気泠却器の設置位 置をどこにするかが問題となる。よつて本論文において はこれらの問題について例題を設定して検討するととも に別子鉱山で実施した通気改善および冷水を利用した坑 内泠却装置について述へる。

\section{2. 通気量と気流温度との関係}

通気量を増加すれば気流温度は低下し，風速の増加と 相まつて坑内気象条件が改善されることは経験上知られ ているが，坑内冷却の設計に当つては通気量を増加した 場合, 果してどの程度の温度降下が期待できるかを定量 的に知ることが必要である。そこでこの問題を例題によ

* 昭和 37 年 4 月 24 日受理

** 工博 住友金属鉱山株式会社 別子制業所铈務裸長代理
つて検討しよう。

いま, 立坑半径を $2.5 \mathrm{~m}$, 岩壁の熱伝導度を $2.92 \mathrm{kcal} /$ $\mathrm{m} . \mathrm{hr} .{ }^{\circ} \mathrm{C}$ 立坑頂部の地熱温度を $30^{\circ} \mathrm{C}$, 坑外空気の年間 平均温度を $15^{\circ} \mathrm{C}$, 水蒸気量を $9.0 \times 10^{-3} \mathrm{~kg} / \mathrm{kg}$, 比重 を $1.2 \mathrm{~kg} / \mathrm{m}^{3}$ と見積り, 立坑は壁面全体が水で濡れて いるものと考えて, 通気量が変化した場合の立坑底の気 流温度および水蒸気量を計算すると第 1 四および第 2

図のようになる。

第1図を見ると，気流が立坑を降下寸る場合には通気 量を増加しても気流温度はあまり低下しないことがわか る。また従来立坑を気流が降下する場合には, 空気の自 己圧縮によつて $100 \mathrm{~m}$ につき約 $1^{\circ} \mathrm{C}$ の温度上昇があると いわれていたが，これは立坑壁面で熱交換が起らず，ま た水の状態変化も起らない場合のことである。実際の坑 内で見られるように立坑壁面が水で濡れている場 合に は，立坑壁面で水蒸気の蒸発がおこり，気流中の水蒸気

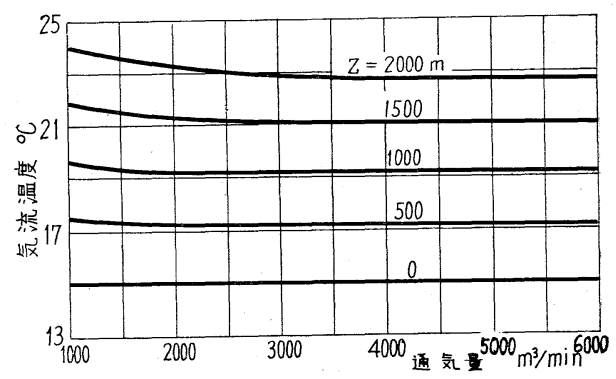

第 1 図気流が立坑を降下する場合の通気量と温度 との比較 


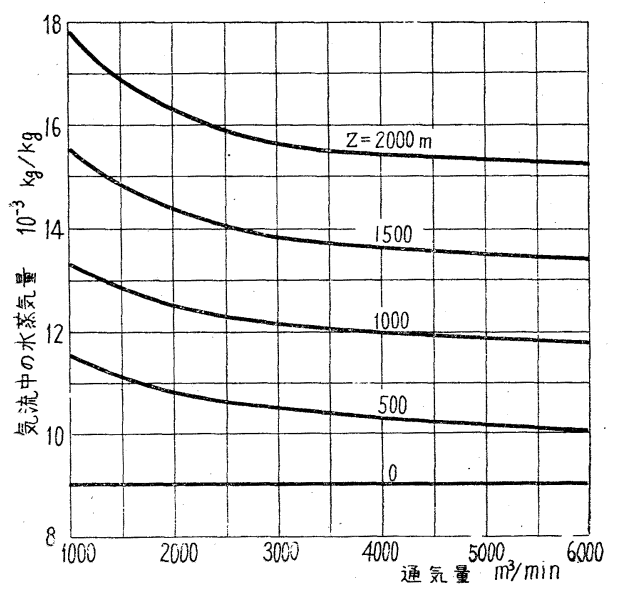

第 2 図気流が立坑を降下する場合の通気量と水蒸 気量々の関係

量が第 2 図に示すように増加するので, 温度上昇はそれ 程高くなく $100 \mathrm{~m}$ 亿つき $0.4 \sim 0.5^{\circ} \mathrm{C}$ 程度である。単位 重量の気流中に含まれる水蒸気量は，第 2 図に示すよう に通気量を増加すると減少する。したがつて立坑の場合 でも通気量を増加すれば，気流温度は低下しないが湿度 が減少する利点がある。

つぎに立坑の深さを $1,120 \mathrm{~m}$ として，この立坑を降下 した入気がさらに $4,500 \mathrm{~m}$ の長さの水平坑道を通過する 場合の温度変化について考える。立坑は前述の条件と同 様とし, 水平坑道の半径注 $2 \mathrm{~m}$, 岩盤の熱伝導度は 2.92 $\mathrm{kcal} / \mathrm{m} . \mathrm{hr} .{ }^{\circ} \mathrm{C}$, 地熱温度は $52.6^{\circ} \mathrm{C}$, 坑道壁面の 湿潤 表面は $3.2 \mathrm{~m}$ と見積つた場合, 立坑底㧍よび水平坑道出口 の気流温度, 水蒸気量が通気量によつてどのように変化 するかを計算すると,第 3 図および第4 図のようになる。

第 3 図から，水平坑道を坑内気流が通過する場合に は，立坑を気流が降下する場合と異なつて，通気量を増 加すれば気流温度は大幅に低下寸ることがわかる。また この温度の低下の割合は, 通気量がある量に達するまで は急激であるが，それ以上になるとだんだん緩慢とな る。例えば $1,000 \mathrm{~m}^{3} / \mathrm{min}$ から $2,000 \mathrm{~m}^{3} / \mathrm{min}$ に通気量 を増加すると気流温度は約 $6^{\circ} \mathrm{C}$ 低下するが， $4,000 \mathrm{~m}^{3 /}$ $\min$ から $5,000 \mathrm{~m}^{3} / \mathrm{min}$ に通気量を増加した場合の温度 低下は僅か $1^{\circ} \mathrm{C}$ にすぎない。

通気量を増加した場合の水蒸気量は，第4図からわか るように,気流温度の低下とほぼ同様の傾向で低下寸る。

さきに, 乾燥した水平坑道を玾内気流が通過する場合 の通気量 $\left(\mathrm{m}^{3} / \mathrm{min}\right)$ は気流温度の上昇度, 通気動力など を考慮すると，坑道延長 $(\mathrm{m})$ の 0.56 ～0.84 倍に上るの が経済的であることを述べたが2)，坑道壁面の一部が水 で濡れている場合にもこの条件が適用できるかどうか検 討してみよう。第 3 図および第 4 図を見ると通気量が $3,000 \mathrm{~m}^{3} / \mathrm{min}$ 以下の時には, 通気量の増加による気流温

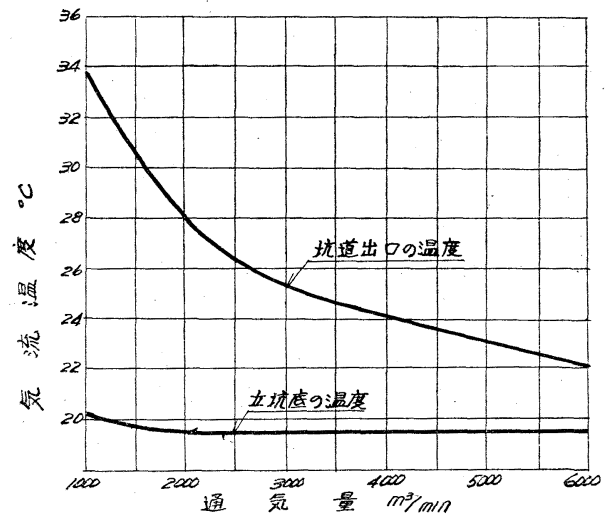

第 3 图通気量と気流温度との関係（水平坑道の場合）

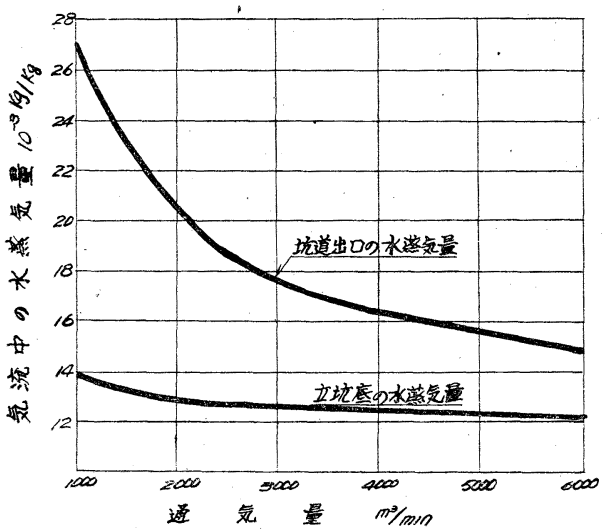

第 4 図 通気量と水蒸気量との関係（水平坑道の場合）

度および湿度の低下が影著であるが，通気量がそれ以上 になると，通気量の増加による温度および湿度の低下は 僅かであることがわかる。この例では坑道延長は 4,500 $\mathrm{m}$ であるから $, 3,000 \mathrm{~m}^{3} / \mathrm{min}$ の通気量は坑道延長の 0.67 倍に当り，この值は前述の $0.56 \sim 0.84$ 倍の範囲内に㐫 る。したがつて，湿つた坑道の場合でも乾燥した抗道と 同じように, 通気量は坑道延長の $0.56 \sim 0.84$ 倍にとる のがよいであろう。

\section{3. 壁面の乾燥状態, 岩盤の熱伝導度, 坑道半 径が気流温度におよぼす影響}

気流が水平坑道を通過する場合には，前節で明らかに したように，気流温度は通気量の多少によつて大幅に変 化するが, 通気量以外に岩盤の乾燥状態, 岩盤の熱伝導 度, 坑道半径などによつても気流温度は変化する。

例えば，坑道入口の気流温度が $19.6^{\circ} \mathrm{C}$, 水蒸気量が, $12.8 \times 10^{-3} \mathrm{~kg} / \mathrm{kg}$, 通気量が $2,000 \mathrm{~m}^{3} / \mathrm{min}$ の場合, 岩 盤温度を, $52.6^{\circ} \mathrm{C}$, 熱伝導度を $2.92 \mathrm{kcal} / \mathrm{m} . \mathrm{hr} .{ }^{\circ} \mathrm{C}$, 坑 道半径を $2 \mathrm{~m}$ と見積つて, 坑道壁面の乾燥状態によつて 気流温度がごのように変化するかを計算すると第 5 図の ようになる。第 5 図から，壁面が完全に乾燥した水平坑 


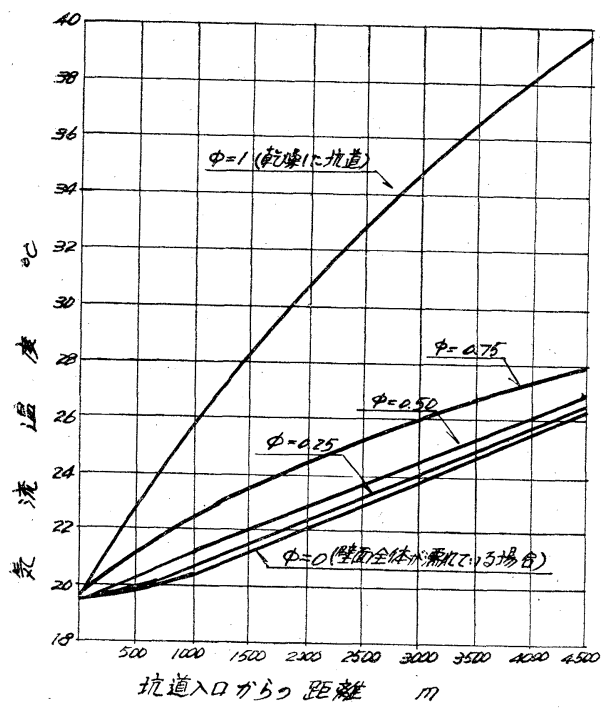

第 5 図坑道壁面の乾燥状態が気流温度に扣よぼす影響

道を気流が通過する場合の温度上昇は極めて急激である が，壁面が多少でも水で濡れている場合には, 気流温度 の上昇度は緩慢となることがわかる。しかし壁面が水で 濡れている場合は, 気流温度は低下するが気流中の水蒸 気量が増加して, 単位重量の空気が有するエンタルピー は隇少しないから, 気流温度を低下させるために坑道壁 面を水で濡らすことは得策ではない。

つぎに，これと同じ例で，坑道壁面の $25 \%$ が水で濡 れている場合, 岩盤の熱伝導度, 坑道半径などによつて 気流温度がどのように変化するかを計算すると第 6 図お よび第7図のようになる。

第 6 図抢よび第 7 図から気流温度の上昇に大きな影響 をおよぼす要因は, 岩盤の熱伝導度の大小で, 坑道半径 の大小の影響は極めて僅かであることがわかる。したが つて, 気流温度の低下を計るためには, 熱伝導度の低、 岩盤の中に通気坑道を開さくすることが大切である。

\section{4. 空気冷却設備の効果について}

空気冷却器を設置して気流を泠却すると, 冷却器を設 置した場所では気流温度は低下するが切羽に達するまで の通気坑道では, 地熱温度々気流温度との差が増加する ので岩盤からの放熱量は増加し, 気流温度の上昇は冷却 される以前よりも迅速となり，冷却老必要とする切羽の 冷却効果は隇退する。したがつて, 空気冷却設備によつ て坑内を人工的に冷却する場合には, 坑内の条件に応し て冷却器の設置位置および通気量を慎重に検討しなけれ ばならない。

いま, 坑外からの入気が $1,120 \mathrm{~m}$ の梁さの立坑を降下 して, さらに $4,500 \mathrm{~m}$ の水平坑道を通過した後, 切羽の ある銿押坑道に通気される場合を考えてみよう。この場

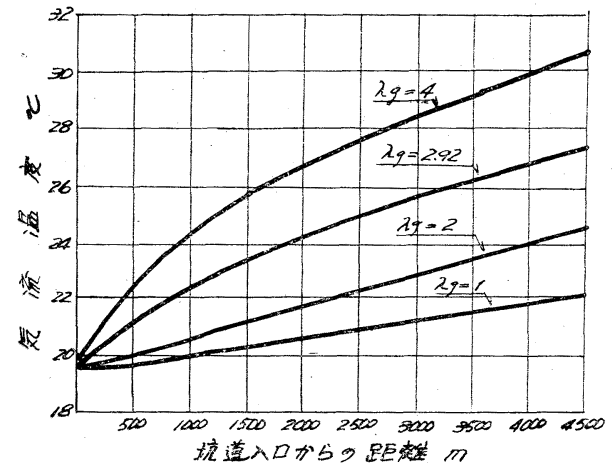

第6図岩盤の熱伝導度が気流温度に扎上ぼす影響

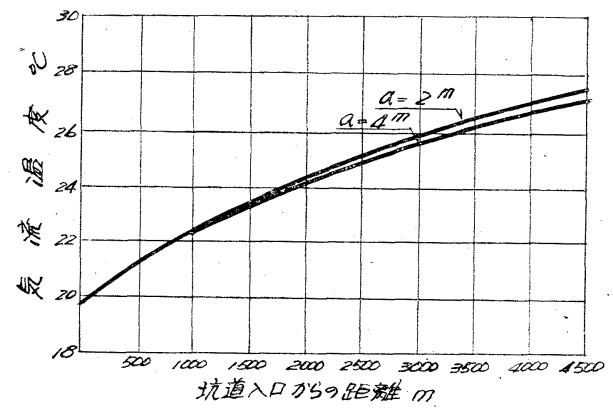

第7图坑道半径が気流温度におよぼす影響 合の立坑㧍よび水平坑道の条件は 2 節で述べた条件上同 ビとし, 坑外には冷却能力 $660,000 \mathrm{kcal} / \mathrm{hr}$ の冷却器を 設置して $, 2,000 \mathrm{~m}^{3} / \mathrm{min}$ の大気を $15^{\circ} \mathrm{C}$ から $5^{\circ} \mathrm{C}$ まで冷 却して坑内に通気するものとする。 $5^{\circ} \mathrm{C}$ まで泠却された 入気㢳立坑㧍よび氷平坑道を通過する間に，ぞのような 温度変化をするか子計算すると第 8 図のようになる。

第 8 四から, 空気冷却器の効果は冷却器少らの距離が 増すにしたがつて隇退することがわかる。すなおち，泠 却器の運転によつて, 冷却器の設置点では $16^{\circ} \mathrm{C}$ の温度 低下があるが，この温度低下は立坑底では $6.6^{\circ} \mathrm{C}$ となり, さらに銿押坑道入口では $3.6^{\circ} \mathrm{C}$ に低下する。冷却器の効 果を比較するために冷却器設置点での温度低下を 1 とし て, 通気路上の各点の温度降下を比較して設置点効率3 と呼ぶことにすると, 設置点効率は第 8 図に示すように 立坑底では 0.66 , 銿押坑道入口では 0.36 となり, 冷却 器の設置点からの距離が増すにしたがつてほぼ值線的に 低下寸る。また気流が立坑を降下寸る場合の方が同じ長 さの水平坑道を気流が通過する場合よりも設置点効率の 低下が大である。このように冷却器の設置点効率は冷却 器から遠ざかるにしたがって低下するので, 空気泠却器 は切羽の近くに設置する方が良い。

第 9 図は通気量が $2,000 \mathrm{~m}^{3} / \mathrm{min}$ の場合と $3,000 \mathrm{~m}^{3}$ / $\min$ の場合の気流の温度変化を比較したものである。

第 9 図から，通気量が $2,000 \mathrm{~m}^{3} / \mathrm{min}$ の場合は 3,000 $\mathrm{m}^{3} / \mathrm{min}$ の場合に比較して冷却器の設置点における温度 


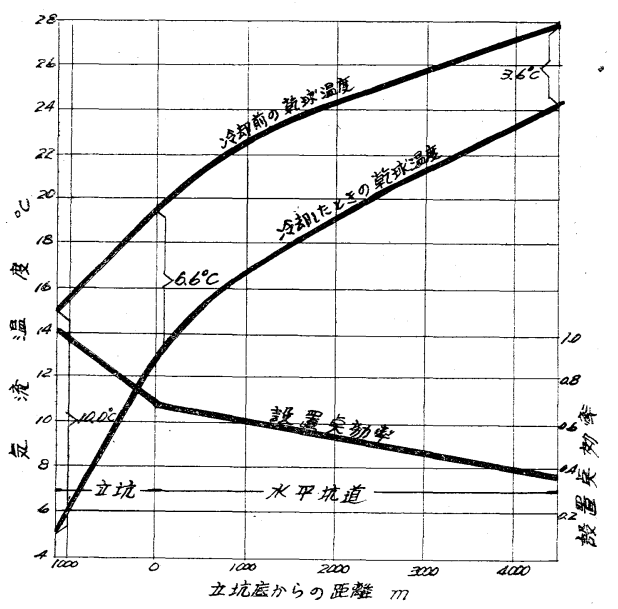

第 8 図 気流の温度経過と設置点效率

低下は大きいが，坑道を通過する際の温度上昇が迅速で 苏るので，設置点から遠ざかるにしたがつて冷却効果が 減退乙, 立坑底から $1,700 \mathrm{~m}$ 以上離れるとかえつて $3,000 \mathrm{~m}^{3} / \mathrm{min}$ の通気量の方が冷却効果が大となること がわかる。このように冷却器の効果は冷却器の設置点, 通気量などによつて変化するから，冷却器を設置する場 合には計算式を用いて気流温度の予測を行なうことが大 切である。

\section{5. 別子鉱山における通気改善について}

別子鉱山においては，以前加ら探鉱通洞に $250 \mathrm{PP}$ の扇 風気を設置して機械通風を行ない，坑内温度の低下を計 つていたが，採鉱切羽が下部に移行するにしたがつて， 地熱温度の上昇と空気の自己珐縮に基因する温度上昇の ため, 坑内温度は急激に上昇し, 温度低下を計らなけれ ば能率のよい採鉱注困難な状態となつた。

暑い坑内を冷却する方法としては，通気量を増加する

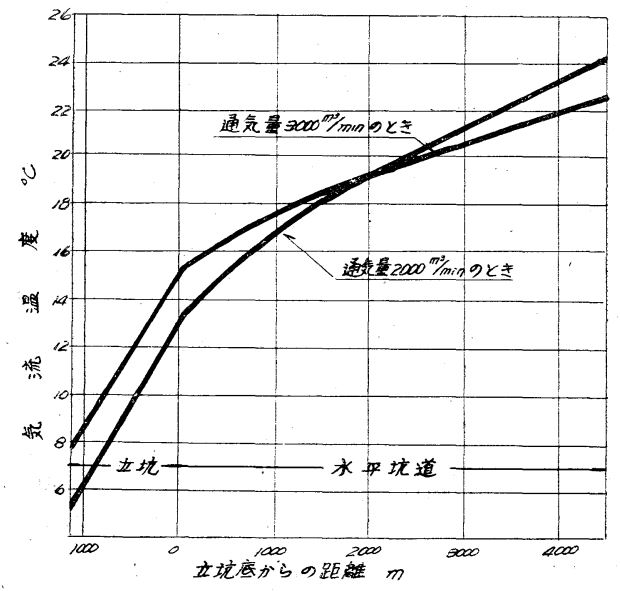

第 9 図通気量による気流の温度変化

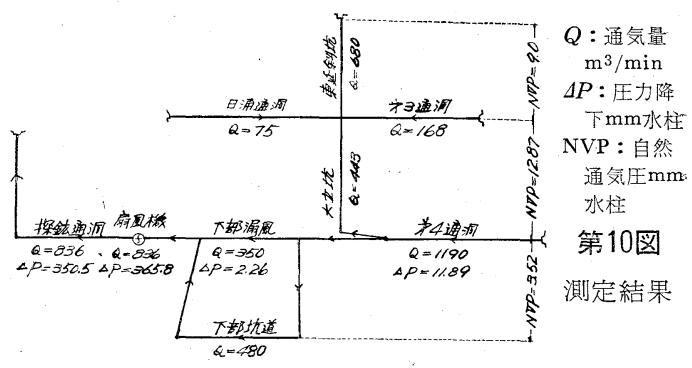

方法と，冷涷機などを使用して坑内を人工的に冷却する 方法とが考えられるが，別子鉱山における当時の通気量 は第 2 節において述べた経済的な通気量に達しない量で あるので，まず第 1 亿通気改善によつて通気量の増加を 計ることを計画し，坑内各部の通気量，比抵抗および自 然通気圧などの測定を行なつた。

第10図は風量および圧力降下の測定結果と温度の測定 結果から計算した自然通気圧の值を示したものである。

ただし図中には, 大立坑の風量と14番坑道面から 8 番 玾道面までの漏風を合成して, これを大立坑の風量とし て表わし, また東延斜坑の風量と 8 番坑道面以上の漏風 を合成して,これを東延斜坑の風量として表わしている。

また $Q$ は通気量 $\mathrm{m}^{3} / \mathrm{min}, \Delta P$ は 2 点間の圧力降下 $\mathrm{mm}$ 水柱, NVP は自然通気圧 $\mathrm{mm}$ 水柱を表わしている。

第10図の測定結果から次の事項が判明した。

(1) 現在の通気系統では，排気坑道である探鉱通洞 の抵抗が非常に大きくて，250H の扇風機で発揮される 通気圧の大部分はこの坑道で消費される。したがつて, 現状の通気系統では, 扇風機の容量を大きくしても通気 量の大幅な增加は不可能である。

(2) 第 4 通洞面以上の自然通気圧は, 坑内外の温度 差が比較的少ない 4 月でも $20 \mathrm{~mm}$ 水柱と言う比較的高い 值を示している。したがって, 通気改善に当つては, こ の作用が扇風機の作用を助けるように考慮しなければな らない。そこでとりあえず第11図のよらな通気系統に改 善することとし, 通気網の計算を行なつだ〉。この計算 結果注図中の数字のようで, 通気系統の変更を行なえば 坑内全般にわたつて通気量が増加することが判明した。

そこで，これを実施するために必要な諸準備を進め, 昭和 27 年 9 月から通気系統の変更を実施した。

通気系統変更後の坑内各部の通気量を測定した結果は

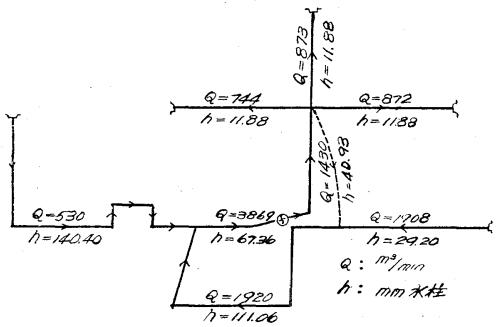

第11図 通気改善後の 通気量の予測 
第 1 表

\begin{tabular}{|c|c|c|c|c|c|c|}
\hline \multicolumn{4}{|c|}{ 通気系統変更後の通気量 $\mathrm{m}^{3} / \mathrm{min}$} & \multicolumn{3}{|c|}{ 通筑改善前の通気量 $\mathrm{m}^{3} / \mathrm{min}$} \\
\hline 風 & 道 名 & 計算 値 & 実湼 值 & 風 & 道 & 実 測 值 \\
\hline \begin{tabular}{l|}
$\lambda$ \\
氛 \\
量
\end{tabular} & $\begin{array}{l}\text { 第 } 4 \text { 通洞 } \\
\text { 探銿洞 } \\
\text { 計 }\end{array}$ & $\begin{array}{r}1,908 \\
530 \\
2,438 \\
\end{array}$ & $\begin{array}{r}1,500 \\
880 \\
2,380 \\
\end{array}$ & 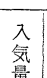 & 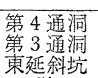 & $\begin{array}{l}630 \\
685 \\
210\end{array}$ \\
\hline 排 & 第 3 涌洞 & 872 & 740 & & & 1,525 \\
\hline 氮 & & 744 & 330 & 排 & 日浦通洞 & 180 \\
\hline 量 & $\begin{array}{l}\text { 果犍斜坑 } \\
\text { 訪 }\end{array}$ & $\begin{array}{r}023 \\
2,439\end{array}$ & $\begin{array}{l}1,400 \\
2,470\end{array}$ & 量 & 探鉱通洞 & $\begin{array}{l}1,390 \\
1,570\end{array}$ \\
\hline $\begin{array}{c}\text { 下䛜 } \\
\text { 部量 }\end{array}$ & $\begin{array}{l}\text { 下部坑道 } \\
\text { 下部渢 }\end{array}$ & $\begin{array}{l}1,920 \\
1,418 \\
\end{array}$ & $\begin{array}{l}2,020 \\
1,040\end{array}$ & 质部量 & $\begin{array}{l}\text { T部坑道 } \\
\text { 下部漏 }\end{array}$ & $\begin{array}{l}940 \\
440 \\
\end{array}$ \\
\hline & 部機風道道 & $\begin{array}{l}1,430 \\
3,869 \\
\end{array}$ & $\begin{array}{l}1,460 \\
3,940 \\
\end{array}$ & & & \\
\hline
\end{tabular}

第 2 表

\begin{tabular}{c|r|r|r|r|r|r|r|r}
\hline & \multicolumn{3}{|c|}{ 昭 和 26} & \multicolumn{3}{|c|}{ 年 } & \multicolumn{3}{|c|}{ 昭 和 28 年 } \\
\cline { 2 - 8 } & 1 月 & 7 月 & 計 & $\%$ & 1月 & 7月 & 計 & $\%$ \\
\hline $29^{\circ} \mathrm{C}$ 以下 & 6 & 5 & 11 & 4.5 & 23 & 13 & 36 & 15.0 \\
$29 \sim 30^{\circ} \mathrm{C}$ & 27 & 25 & 52 & 21.6 & 46 & 40 & 86 & 35.9 \\
$31 \sim 33^{\circ} \mathrm{C}$ & 36 & 41 & 77 & 32.0 & 28 & 32 & 60 & 25.0 \\
$33 \sim 35^{\circ} \mathrm{C}$ & 35 & 25 & 60 & 24.9 & 15 & 22 & 37 & 15.4 \\
$35^{\circ} \mathrm{C}$ 以上 & 17 & 24 & 41 & 17.0 & 8 & 13 & 20 & 8.7 \\
許 & 121 & 120 & 241 & 100.0 & 120 & 120 & 240 & 100.0 \\
\hline
\end{tabular}

第 1 表に示す。第 1 表を見ると, 通気網の計算結果から 予測した通気量と通気系統变更後に実測した通気量との 間には，余り大きな差異がないことがわかる。探鉱通洞 の通気量の実測結果が計算值よりも増加しているのは, 一部崩落していた坑道の取明け作業を実施したため，こ の坑道の比抵抗が減少したからである。このように坑内 各所の通気量が増加したため, 坑内温度は第 2 表に示す ように低下した。

第 2 表は昭和 26 年と昭和 28 年の温度別の切羽数を比較 したもので,この表から昭和 26 年には $31^{\circ} \mathrm{C}$ 以上の温度 の切羽数が全切羽数の $74 \%$ を占めていたのが, 通気系 統を変更した後の昭和 28 年には $49 \%$ に減少している。

\section{6. 冷水による坑内冷却について ${ }^{5)}$}

前節で述心゙たよに別子鉱山の気象条件は通気改善に よつてかなり改善されたが，今後の採鉱の主力となる18 番坑道面以下の温度はなお相当高温度であり, また, 終 戦後の探鉱によつて全面的に採鉱することに計画変更さ れた中部の東山地帯（大正末期以前に低品位鉱として採 掘跡に充壃された鉱石）も採鉱が進むにしたがつて作業 環境が悪化してきた。そこでこれが解決を人工的な冷却 装置を利用した気流循環方式によつて計ることとし，第 12図に示すような通気方式を採用した。

これは，第 4 通洞および探鉱通洞からの入気を東立坑 (一部西斜坑) から降下させて, 下部各坑道の切羽を通 気した後, 3 号斜坑に合流させ, 新立坑を経て, 14番坑 道風道に据付けられた $600 \mathrm{P}$ 扇風機（現在は回転数を低 下させて $300 \mathrm{P}$ で運転している。索過するような通気 系統である。扇風機を通過した後の排気は, 大立坑を経 て，一部は東風として中部地帯の各切羽を通り，再たで 14番坑道に下つてもう一度扇風機を通過する。残りの部

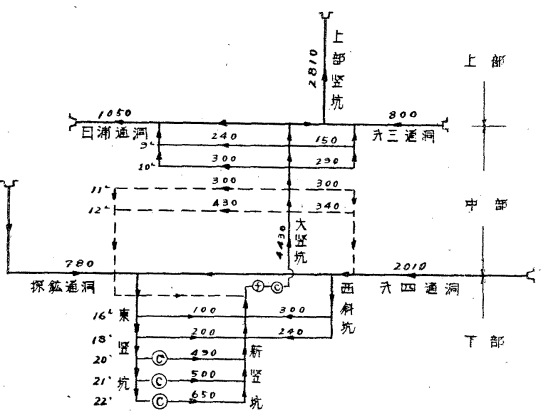

(†) 扇風機 (C) 空気冷却器 L 坑道 図中の数字は 36 年 3 月の通気量 $\mathrm{m}^{3} / \mathrm{min}$

第12図 別子鉱山の通気系統図

分は上部立坑, 日浦通洞などから坑外に排出される。な お中部地带に循環する気流と, 下部各坑道に分流する気 流の温度を低下させるために，14番坑道風道および20番 坑道, 21 番坑道, 22 番坑道に冷水を利用した空気冷却装 置を設置した。

空気泠却装置の冷却容量および泠却コイルの仕稼は第 3 表および第 4 表に示す。

空気循環方式を採用するに当つて, もつとも心配した 点は空気污染の問題である。金属鉱山では炭鉱のように 爆発性のガスが湧出する恐れはないが，坑木执よび鉱石 の酸化作用ならびに人員の呼吸による炭酸ガスの発生, 酸素の欠乏などが起り，また発破のあとガスの発生があ る。これらの原因による有害ガスの発生量は, 従来の経 験がら，通気量に比べると僅かな量であることは推定さ れるが，空気德環方式を採用した場合，有害ガスが累積 して許容量以上になるようなことがあれ!゙この方法は採 用されなくなる。しかし実施後の空気分析の結果では， 炭酸ガスの含有量は $0.05 \%$ 程度で累積の傾问はなく,

第 3 表

\begin{tabular}{|c|c|c|c|c|c|c|c|c|}
\hline & \multicolumn{2}{|c|}{$\begin{array}{l}\text { 14L排㽞 } \\
\text { 泠却 }\end{array}$} & \multicolumn{2}{|c|}{20 L治却器 } & \multicolumn{2}{|c|}{21 L椧却器 } & \multicolumn{2}{|c|}{22 L冷却器 } \\
\hline & 乾球 & 湿球 & 乾球 & 湿球 & 乾球 & 湿球 & 乾球 & 湿球 \\
\hline \multirow{2}{*}{ 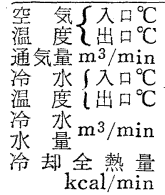 } & $\begin{array}{r}31.5 \\
26.0 \\
4 \\
1 \\
2\end{array}$ & $\begin{array}{l}30.0 \\
26.0 \\
000 \\
.0\end{array}$ & $\begin{array}{r}31.0 \\
24.0 \\
5 \\
1 \\
2\end{array}$ & $\begin{array}{l}30.5 \\
24.0 \\
00 \\
3.0 \\
.8\end{array}$ & $\begin{array}{r}31.0 \\
24.0 \\
5 \\
1 \\
2\end{array}$ & $\begin{array}{l}30.5 \\
24.0 \\
00 \\
3.0 \\
.8\end{array}$ & $\begin{array}{r}31.0 \\
24.0 \\
7 \\
18 \\
26\end{array}$ & $\begin{array}{l}30.5 \\
24.0 \\
50 \\
8.0 \\
.8\end{array}$ \\
\hline & & $\begin{array}{l}4 \\
900\end{array}$ & & $\begin{array}{l}50 \\
400\end{array}$ & & $\begin{array}{l}50 \\
400\end{array}$ & & $\begin{array}{l}75 \\
600\end{array}$ \\
\hline
\end{tabular}

第 4 表

\begin{tabular}{|c|c|c|c|c|}
\hline & $14 \mathrm{~L}$ 排気冷却 & 20L冷却器 & 21 L冷却器 & 22 L冷却器 \\
\hline $\begin{array}{l}\text { フイインパイプの } \\
\text { 有効長 }\end{array}$ & \multirow{6}{*}{$\begin{array}{c}7 '-6^{\prime \prime} \\
30 \text { 本 } \\
1 \text { 时沉 } 6 \text { 枚 } \\
8 \text { 列 } \\
\text { アルブラック } \\
\text { 管 } \\
\%^{\prime \prime} \times 1.2 \mathrm{~mm} \\
0.26 \mathrm{~mm} \\
5 \text { 台 }\end{array}$} & \multirow{6}{*}{ 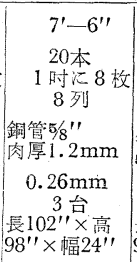 } & \multirow{6}{*}{$\begin{array}{c}7^{\prime}-6^{\prime \prime} \\
30 \text { 本 } \\
1 \text { 时沉6放 } \\
8 \text { 列 } \\
\text { アルプラック } \\
\text { 管 } \\
5 \% \times 1.2 \mathrm{~mm} \\
0.26 \mathrm{~mm} \\
2 \text { 台 } \\
\text { 長 } 102^{\prime \prime} \times \text { 高 } \\
93^{\prime \prime} \times \text { 腷 } 24^{\prime \prime}\end{array}$} & \multirow{6}{*}{ 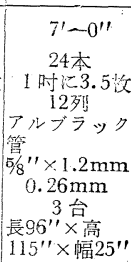 } \\
\hline 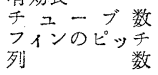 & & & & \\
\hline フィンパイプ & & & & \\
\hline 銅フィン & & & & \\
\hline & & & & \\
\hline 外法寸法 & & & & \\
\hline
\end{tabular}




\section{第 5 表}

\begin{tabular}{|c|c|c|c|c|c|c|}
\hline \multirow{2}{*}{ 時 刻 } & \multicolumn{3}{|c|}{ 入気倒 (東立坑16L 胃合) } & \multicolumn{3}{|c|}{ 排気側 ( 3 号斜坑 $16 \mathrm{~L}$ 見合) } \\
\hline & $\mathrm{O}_{2}$ & $\mathrm{CO}_{2}$ & $\mathrm{CO}$ & $\mathrm{O}_{2}$ & $\mathrm{CO}_{2}$ & $\mathrm{CO}$ \\
\hline $\begin{array}{r}9.00 \\
11.00 \\
12.00 \\
13.00 \\
14.00 \\
14.40\end{array}$ & $\begin{array}{l}20.4 \\
20.2 \\
20.2 \\
20.0 \\
20.2\end{array}$ & $\begin{array}{l}0.02 \\
0.04 \\
0.03 \\
0.04 \\
0.05\end{array}$ & 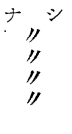 & $\begin{array}{l}20.6 \\
20.2 \\
20.2 \\
20.0 \\
20.4 \\
20.2\end{array}$ & $\begin{array}{l}0.03 \\
0.02 \\
0.03 \\
0.04 \\
0.05 \\
0.04\end{array}$ & $\begin{array}{l}\text { ナシ } \\
\text { "I" } \\
\text { "'" } \\
\text { "' }\end{array}$ \\
\hline
\end{tabular}

第 6 表

\begin{tabular}{|c|c|c|c|}
\hline 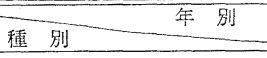 & 30年 & 31 年 & 32年 \\
\hline 坑内全作業場の平均温度 & $32.0^{\circ} \mathrm{C}$ & $29.7^{\circ} \mathrm{C}$ & $28.3^{\circ} \mathrm{C}$ \\
\hline 坑内夫 1 工当出鉱量 $\{\mathrm{t} / \mathrm{I}$ & $\begin{array}{l}1.39 \\
100\end{array}$ & $\begin{array}{l}1.47 \\
106\end{array}$ & $\begin{array}{l}1.63 \\
117\end{array}$ \\
\hline 1 力月当平均㷋害 件/月 $^{2}$ & 44 & 25 & 18 \\
\hline 数 \{ & 100 & 57 & 41 \\
\hline
\end{tabular}

第 7 表

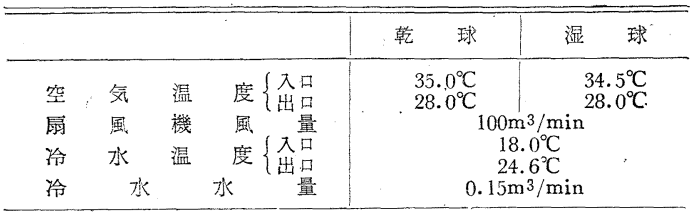

一酸化炭素などの有害ガスも認められなかつた。また気 流中の岩粉量は空気冷却器によつて約 $44 \%$ 除去するこ とができた。

空気成分注循環気流の割合が増加するにしたがつて恶 くなると考兄れるので, 試みに第12図に示寸通気系統 の扇風機出口付近汇設置してある入排気遮断の通気屝を 開放して, 循環気流量を増加して見た。この場合の入気 量法, $1,760 \mathrm{~m}^{3} / \mathrm{min}$, 循環気流量は $3,280 \mathrm{~m}^{3} / \mathrm{min}$, 扇 風機を通過する総風量は $5,040 \mathrm{~m}^{3} / \mathrm{min}$ であつた。第 5 表はこの場合の下部坑道の入気側と排気側の空気成分を 分析した結果を示す。

第 5 表の分析結果から, 総風量の $35 \%$ 程度の入気量 を補給すれば, 循環気流中に一酸化炭素は認められず, 炭酸ガスの量は $0.05 \%$ 以下，酸素の含有量は $20 \%$ 以 上に保たれ，労務者の保健衛生上差支えない空気成分で あることがわかつた。また入気側と排気側の空気成分に 差異がないことから, 坑内で発生する一酸化炭素や炭酸 ガスなどの有害ガスの量は通気量に比べると極めて僅か な量であることが推測される。

このように気流循環方式を採用することにより，2,800 $\mathrm{m}^{3} / \mathrm{min}$ (第 3 通洞からの入気量を除く) の入気量で中 部地寡に $2,400 \mathrm{~m}^{3} / \mathrm{min}$, 下部に $2,500 \mathrm{~m}^{3} / \mathrm{min}$, 合計 $4,900 \mathrm{~m}^{3} / \mathrm{min}$ の空気量を採鉱切羽に通気することがで き, 採鉱切羽の温度も低下した。

第 6 表は別子鉱山における過去 3 力年間の坑内夫 1 工 当り出鉱量, 1 力月当り災害件数ならびに坑内全作業場 の平均温度の変化を示したものである。第 6 表から, 坑 内温度の低下儿ともなつて, 採鉣工程は上昇し, 災害件
数は隇少していることがわかる。これらは坑内における 種々の技術改善の結果によるものであるが，温度低下が 大きな役割を演じているものと考えられる。なお気象条 件の改善によつて温度手当の支給額は年間 330 万円減少 した。

なお，掘進切羽などの盲坑道には，クーラーと扇風機 を同じ台車の上に乘せ，移動が自由にできるように設阡 した局部冷却器を使用している。この冷却器の仕様は第 7 表のようである。

\section{7. 結論}

本論文においては，まず，氛流温度に影響をおよぼす 要因および冷却器を用いて坑内を人工的に冷却する場合 の設置点効率について検討した。そしてその結果から次 の事項を明らかにした。

（1）従来立坑を気流が降下寸る場合には，空気の自 己圧縮によつて $100 \mathrm{~m}$ につき $1^{\circ} \mathrm{C}$ の温度上昇があると云 われていたが，これは立坑壁面で熱交換がおこらず，ま た水の状態変化がおこらない場合のことで，実際の坑内 で見られるように立坑壁面が水で濡れている場合の温度 上昰は $100 \mathrm{~m}$ につき $0.4 \sim 0.5^{\circ} \mathrm{C}$ 程度である。

（2）気流が立坑を降下する場合には通気量を増加し ても気流温度の低下は僅かであるが; 水平坑道の場合に は通気量を増加すると気流温度は大幅に低下する。ま た，通気量が一定の場合には気流温度は主として岩盤の 熱伝導度, 壁面の濡れの程度によつて変化し, 坑道半径 の大小によつては余り変化しない。

（3）冷却器の効果は冷却器から遠ざかるにしたがつ て低下するから, 泠却器は切羽の近くに設置することが 望ましい。管理上の要請から冷却器を坑外に設置する場 合には, 坑外加ら切羽までの距離と通気量によつて冷却 効果が変化するので, 冷却器の容量および通気量は気流 温度の計算を行なつて決定しなければならない。

ついで，別子鉱山において実施した通気改善および冷 水による坑内泠却法について論述し，これらを実施する ことによつて別子鉱山の気象条件は改善され，深部採鉱 の解決に曙光を見出したことを述べた。

本研究に当り種々御指導を賜つた京大平松教授ならび に当社岩沢常務, 戸倉別子鉱業所長, 飯泉副所長に深く 感謝する次第である。

\section{参考文 献}

1) 平松・天野・小門：坑内気流温度の実用計算, 日本捈業会誌 77 巻 882最 昭和 36 年 12 月 p. 1055.

2) 天野: 主要通気坑道を坑内気流が通過する場合の温度就上び湿度の 翌化について, 水珤会誌 13 巻 9 号 昭和 33 年 4 月 p. 715 .

3) Siegfried Batzel: Glückauf, Bd. 95, 1959.

4) 平松・岡：通気網の解法汇ついて(第 2 報)，日本釷業会誌 68 巻 771 号 昭和 27 年 9 月 p. 431.

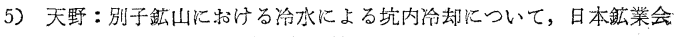
誌 75 巻 852 号 昭和 34 年 6 月 p. 381 . 